\title{
Identification of Economic and Social Measures on Reformation of Urban Eroded Context (Case Study: Shahr-E-Kord City Eroded Context)
}

\author{
Morteza Ghaed Amini $^{{ }^{*}}$, Roghayeh Vadayeh Kheyri \\ ${ }^{I}$ Department of Urban Planing, West Tehran Branch, Islamic Azad University, Tehran, Iran. \\ ${ }^{2}$ Department of Urban Planing, Robat Karim Branch, Islamic Azad University, Robat Karim, Iran.
}

\begin{abstract}
Cities are alike living beings that are consistently in need of instauration and require restoration and reconstruction of withered tissues and replacement of new cells with the old ones. The eroded context of Shahr-e-kord city is one of the eroded and valuable fabric samples which is facing social, economic, and skeletal evolutions due to problems such as social and economic degradation, skeletal erosion, etc. Given that, the subject of this research that is the reformation of Shahr-e-kord eroded context was chosen and reviewed due to the significance of social and economic studies.

Achieved findings from final evaluation through SWOT factors in of AHP model depicts that in strength points, long settlement of people's in context and integration of available potentials in context for reformation are the most important strengths, and the population mitigation in area and descending value of its functions are the most important threats.

Today, the main problem of under study context is the low affordability and disproportion of expenses and incomes of families in eroded context. Based on final analyses in this research, substantial propositions to benefit from the strengths, opportunities, declination of weaknesses and threats in form of SWOT model strategies are suggested for reformation of Shahr-e-kord eroded context.
\end{abstract}

Keywords: Eroded context, reformation, economic, social, Shahr-e-kord.

\section{Introduction}

Since the early $13^{\text {th }}$ century, by getting into power of Reza Khan (1920) and establishment of security, the fort and gate of the city were fallen down and the first intervention in modernism and skeletal-spatial structure of archaic context was begun. Today, the old fabric consists of a part of urban context which is a result of developments prior to 1300 Hijri and mostly self-organized. These contexts regardless of skeletal exhaustions represent the historical identity of city and are of locational, spatial, historical and social values (Khademi, 2000: 66). Yet today, these contexts are facing with erosion and destruction, so that an important part of these districts' population is relocated. The old and archaic fabric of Shahr-e-kord is not excluded and it is facing with multiple problems. The archaic context of Shahr-e-kord has the area of about 86 acres.

It covers 4 percent of Shahr-e-kord urban zone and has the half of urban traffic.

One of generating factors of urban eroded fabrics' problems, is the unplanned development of these cities. In case of Shahr-e-kord city, the sprawl of the city northward and southward has progressively mitigated the skeletal and functional centrality of city's archaic neighborhood, so that, these neighborhoods have been remained in their archaic past. This issue has led to immigration of long-term settlers of context or the replacement of rural immigrants and nomads, brings about the social transformation of texture and new residents have no strong dependence to the context and no interest toward investment in it.
As a result, progressive renovation of fabric units is stalled that it could be able to inhibit its collapse and for this, the context framework tends to erode. Further, the weak bond between two new and old fabrics also leads to functional fragility of archaic context.

The dominant approach of this research is based on functional objective an analytic-descriptive nature which the social and economic indexes have been analyzed by evaluation models AHP and SWOT. Eventually, it provides policies to reach to sustainable development with the perspective of future to solve the problems pertaining to the considered area.

\section{Theoretical Concepts of Research}

The concepts have been constantly considered in research are as follows:

\section{Context}

The city context that consists of the interweaving of spaces and urban elements have been replaced following to natural conditions, topography and climate in particular, densely or dispersedly, or in a specific order in urban area, that is, city blocks and neighborhoods (Farid, 1994: 96).

\section{Archaic Context}

The archaic context is that sort of integrity of residence and the solidarity of skeletal spaces which belongs to the old social order 
in which the social life system was differentiated from today's social one (Tavasoli, 2003: 5).

\section{Eroded Context}

Whenever activities and use meet the requirements but the framework is damaged or the activity system is messed up and uses are defected but the framework has been preserved, the erosion is proportional and whether both types of erosion occur, it is thorough (www.udro.org.ir).

\section{Reformation}

About reformation, multiple definitions have been provided by city and urban development specialists and scholars which here some of them are pointed. Reformation suggests some interventions which would be attended for maintenance and improvement of city framework and space in a short-term period (Habibi, Maghsoudi, 2002: 18).

\section{Renovation}

Renovation and rehabilitation of urban eroded districts through improvement of these areas like introducing modern services in old residential areas or by instauration of the alleys or reformation (destruction of all available constructions and their reconstruction) (Wilson James, 1973: 85).

\section{Reconstruction}

Are the activities which take to action after the demolition of over half of the structure with a new use or perfectly compatible with its rules, generally the reconstruction is integrated at the time of fire, Earth-trembling or war (Habibi, 2005: 16).

\section{Urban Instauration Theory}

Urban instauration as resurrection or revitalization of some parts of urban areas which have no common standards. Therefore, the urban instauration or modification of eroded archaic constructions and their replacement through development of new constructions, streets, and parks. In many countries, the state policies are tended to urban instauration so-called housing (Poal Balchin,1988: 252).

\section{Authentication Theory}

Some of these theories believe in renovation, some in reformation and some in a combination of renovation, reformation and protection. One of the instauration policies of residential quarters (adjacent units) in this part of city authenticating theory or dwelling improvement policy together with the amelioration of residence conditions in area particularly for high-income young, and low-child bearing groups (Juliet Carpenter and Lortt Alees, 1995: 280-283).

\section{Methodology}

The research is functional from the goal aspect and as to the methodology, it is a combination of documentary, analytic, and descriptive methods.

\section{Data Collection Tools}

Data collection tool is through filling questionnaire, field studies, plotting, library resources, and internet.

\section{Data Analysis Tool}

Descriptive models and methods and Expert choice and EXCEL applications have been integrated.

\section{Discussion}

\section{The Review of Problems Pertaining to Shahr-E-Kord Eroded Context through SWOT Technique}

The urban problematic context is of fabrics that the existence of different elements and factors in it, results in mitigation of qualitative values for human environment and the importance of residential values, renovation in context halts and tendency toward immigration enhances in residences (Jahanshahi, 2003: 18).

These areas are not capable of self-renovation and the investors are not encouraged for the investment. According to the principles and suggested theories we proceed to the problems of Shahr-ekord and providing solutions to resolve these issues in form of SWOT tables. To study the problems through SWOT technique, first we classify the internal factors for strengths and weaknesses and external factors for opportunities and threats. SWOT is the abbreviation of four English terms that are strength, weakness, opportunity and threat. SWOT analysis is consisted of identification of factors that it should bear the best compatibility with them. The rationale and approach is that the effective strategy, should maximize the strengths and opportunities of system, and minimize threats and weaknesses. This rationale whether integrated appropriately or not, will result in desirable results to choose and design an effective strategy.

Table 1: The Review of Strengths, Weaknesses, Threats, and Opportunities in Shahr-e-Kord Eroded Context

\begin{tabular}{|l|l|}
\hline External factors & Internal factors \\
\hline Opportunities (O) & Strengths (S) \\
\hline $\begin{array}{l}\text { O1- integration of available } \\
\text { potentials in context for } \\
\text { renovation. }\end{array}$ & S1- context reformation \\
\hline $\begin{array}{l}\text { O2- elevation of district } \\
\text { economic level. }\end{array}$ & $\begin{array}{l}\text { S2- high tendency of people for } \\
\text { reformation in context }\end{array}$ \\
\hline $\begin{array}{l}\text { O3- potential to set up } \\
\text { regulations due to the location in } \\
\text { historical fabric. }\end{array}$ & S3- people long residence in context. \\
\hline $\begin{array}{l}\text { O4- potential to attract private } \\
\text { capital as to private possession. }\end{array}$ & $\begin{array}{l}\text { S4- concentration of economic } \\
\text { activities }\end{array}$ \\
\hline $\begin{array}{l}\text { O5- profitability possibility and } \\
\text { more economic exploitation are } \\
\text { provided. }\end{array}$ & $\begin{array}{l}\text { S5- availability of valuable historical } \\
\text { elements }\end{array}$ \\
\hline Threats (T) & Weaknesses (W) \\
\hline $\begin{array}{l}\text { T1- transformation of context to } \\
\text { a mere commercial context and } \\
\text { ignoring other individuals' needs }\end{array}$ & W1- low literacy of people in area \\
\hline $\begin{array}{l}\text { T2- degradation of security in } \\
\text { neighborhood }\end{array}$ & $\begin{array}{l}\text { W2- disproportion of expense and } \\
\text { income of families in eroded fabric }\end{array}$ \\
\hline $\begin{array}{l}\text { T3- modification of ruined } \\
\text { spaces to center of criminals and } \\
\text { outlaws }\end{array}$ & $\begin{array}{l}\text { W3- insecurity due to wastelands, } \\
\text { abandoned and ruined lands }\end{array}$ \\
\hline $\begin{array}{l}\text { T4- limited affordability of } \\
\text { residents to contribute in context } \\
\text { reformation }\end{array}$ & $\begin{array}{l}\text { W4- low contribution of residents in } \\
\text { reformation of eroded fabric }\end{array}$ \\
\hline $\begin{array}{l}\text { T5- uncertainty of investors to } \\
\text { return of investment in fabric }\end{array}$ & $\begin{array}{l}\text { W5- unwillingness of investors for } \\
\text { investment in reformation of area }\end{array}$ \\
\hline Resource: Research findings & \\
\hline
\end{tabular}

Resource: Research findings

\section{The Analysis of Under-Study Area by Applying SWOT Model}

It should be said that the SWOT analysis has some deficiencies as a significant tool in strategic planning, like in time of integrating this model, the analysis is not capable of comprehensive evaluation of decision making situation and it mostly determines 
the list of certain factors in strength, weakness, opportunity, and threat groups. As, the planning procedure mostly embraces many standards and their interdependencies.

It is possible that the integration of SWOT model would not be solely sufficient, therefore, as for the above subjects and to advance the efficiency in strategic planning, the most important policy in this research, is the integration of SWOT and AHP models.

AHP is a method that provides required conditions for quantification of SWOT factors and accommodating the evaluation possibility of decision making situations by SWOT model.

In this combination SWOT provides the framework in which, the analysis of decision-making is carried out and AHP model is also integrated for prioritization of SWOT factors and then for prioritization of SWOT groups. Meanwhile, in order to ameliorate the quality analysis of AHP-SWOT models, several experts in the field of urban eroded contexts and urban planning that are familiar with the under-study area or live there, are demanded to participate in weighting the SWOT elements in form of AHP model.

Hierarchical procedure of AHP is a flexible, potent, and simple that is adopted in decision making in conditions that harnesses the selection procedure between choices. AHP is one of most comprehensive designed systems for decision-making with multiple scales, because this model provides the formulation of case in a hierarchical way and further, it is able to consider different qualitative and quantitative elements in case. Moreover, this procedure engages different options in decision-making and entails the capability of sensitivity analysis on standards and substandards; likewise, it is established based of peer comparison that facilitates judgments and computations and also represents the compatibility and incompatibility degrees of decision-making process and this is of the privileged prerogatives of this model in multi-scale decision-making process (Ghodsi Poor, 2005: 5).

This method consists of three following steps:

A) generation of dual matrix comparison

B) scale weights calculation

C) estimation of agreement ratio

D) on this basis, the peer comparison of SWOT elements in form of AHP has made in eroded context of Shahr-e-kord, then weighted and prioritized which the results are as follows.

Table 2: Peer Comparison of Factors in Strengths of Shahr-E-Kord Eroded Context

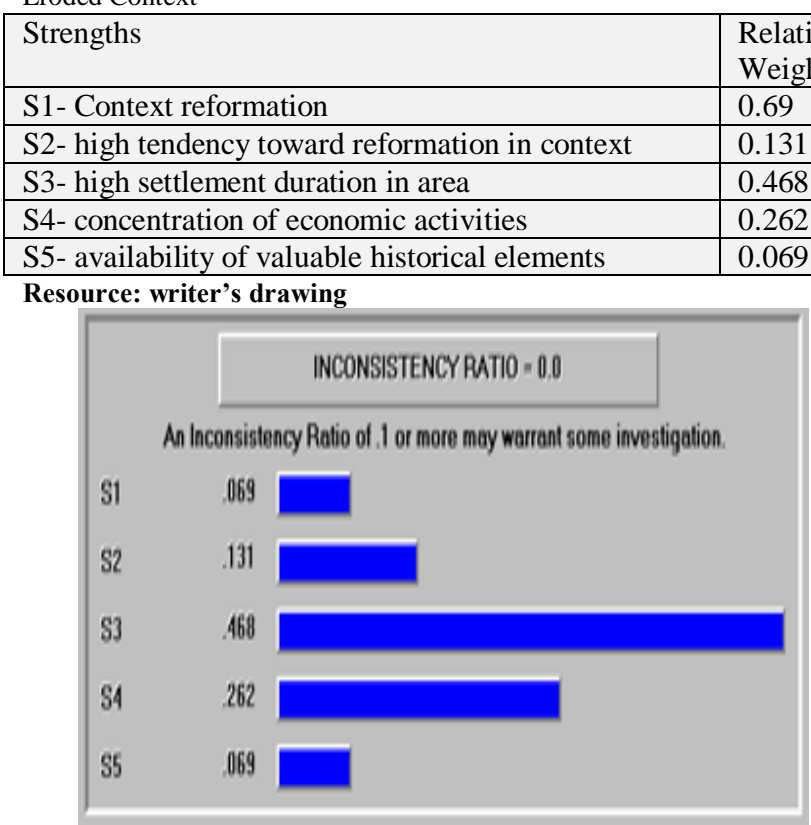

Fig. 1: Final weight of each strength (SWOT-AHP)

Resource: writer's drawing
Table 3: Peer Comparison of Elements in Opportunity Group of Shahr-EKord Opportunity Points

\begin{tabular}{|l|l|}
\hline Opportunities & $\begin{array}{l}\text { Relative } \\
\text { weight }\end{array}$ \\
\hline $\begin{array}{l}\text { O1- adoption of available potentials in area for } \\
\text { reformation }\end{array}$ & 0.064 \\
\hline O2- enhancement of area's economic level & 0.455 \\
\hline $\begin{array}{l}\text { O3- the potential to set up regulations in order to } \\
\text { locate in historical context area }\end{array}$ & 0.120 \\
\hline $\begin{array}{l}\text { O4- potential to attract private investment regarding } \\
\text { private ownership }\end{array}$ & 0.240 \\
\hline $\begin{array}{l}\text { O5- provides more possibility of profitability and } \\
\text { economic exploitation }\end{array}$ & 0.120 \\
\hline
\end{tabular}

Resource: student's drawing

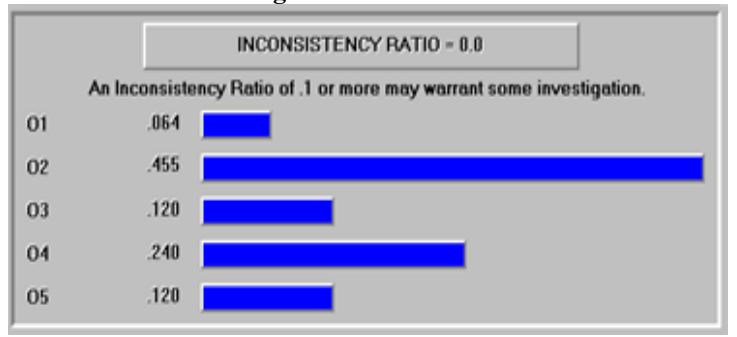

Fig. 2: Final weight of any opportunity points (SWOT-AHP) Resource: writer's drawing

Table 4: Peer comparison of Factors in Threats Group of Shahr-E-Kord Eroded Context

\begin{tabular}{|l|l|}
\hline Threats & $\begin{array}{l}\text { Relative } \\
\text { weight }\end{array}$ \\
\hline $\begin{array}{l}\text { T1- transformation of context to a mere commercial and } \\
\text { ignoring other individuals' needs }\end{array}$ & 0.120 \\
\hline $\begin{array}{l}\text { T2- procedure of area descending population and falling } \\
\text { value of its functions }\end{array}$ & 0.240 \\
\hline $\begin{array}{l}\text { T3- modification of context ruined spaces to a center for } \\
\text { criminals and outlaws }\end{array}$ & 0.455 \\
\hline $\begin{array}{l}\text { T4- expansion of social problems and harms in eroded } \\
\text { context area }\end{array}$ & 0.120 \\
\hline T5- uncertainty of investors toward investment return in area & 0.064 \\
\hline
\end{tabular}

Resource: student's drawing

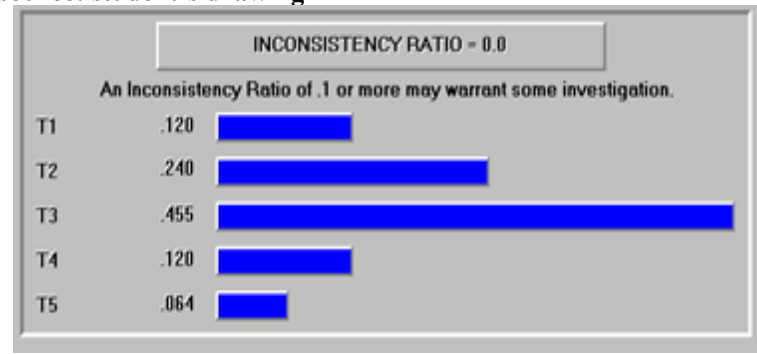

Fig. 3: Final weight of any threat points (SWOT-AHP)

Table 5: Peer comparison of Factors in Weakness Group of Shahr-e-kord Context

\begin{tabular}{|l|l|}
\hline Weaknesses & $\begin{array}{l}\text { Relative } \\
\text { weight }\end{array}$ \\
\hline W1- low literacy of settlers & 0.180 \\
\hline $\begin{array}{l}\text { W2- disproportion of expenses and incomes of eroded } \\
\text { context families }\end{array}$ & 0.340 \\
\hline $\begin{array}{l}\text { W3- insecurity due to existence of wastelands, abandoned } \\
\text { and ruined lands }\end{array}$ & 0.090 \\
\hline $\begin{array}{l}\text { W4- low collaboration of residents in reformation of eroded } \\
\text { context area }\end{array}$ & 0.340 \\
\hline $\begin{array}{l}\text { W5- low contribution in investment of investors in context } \\
\text { reformation }\end{array}$ & 0.051 \\
\hline
\end{tabular}

Resource: student's drawing 


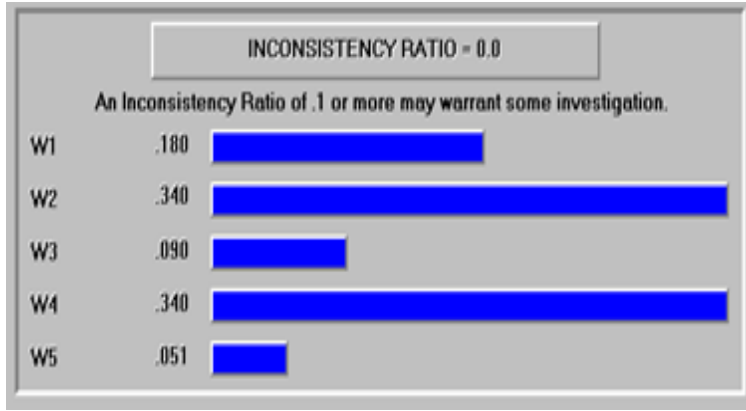

Fig. 4: Final weight of any strengths (SWOT-AHP)

Resource: writer's drawing

Table 5: Intergroup Initial Priority Matrix of SWOT Factors in Line with Optimization of Shahr-E-Kord Eroded Context

\begin{tabular}{|c|c|c|}
\hline Intergroup SWOT factors & $\begin{array}{l}\text { Initial } \\
\text { priority }\end{array}$ & $\begin{array}{l}\text { Priority } \\
\text { order }\end{array}$ \\
\hline S3- long settlement of individuals in context & 1 & 1 \\
\hline S4- concentration of economic activities & 2 & 2 \\
\hline O2- enhancement of district economic level & 3 & 3 \\
\hline $\begin{array}{l}\text { O4- potential to attract private capital regarding } \\
\text { private ownership }\end{array}$ & 4 & 4 \\
\hline $\begin{array}{l}\text { S2- high tendency of people in reformation of } \\
\text { context }\end{array}$ & 5 & 5 \\
\hline $\begin{array}{l}\text { W2- disproportion of expense and income of } \\
\text { families in eroded area }\end{array}$ & 6 & 1 \\
\hline $\begin{array}{l}\text { W4- low contribution of settlers in reformation } \\
\text { of eroded context area }\end{array}$ & 7 & 2 \\
\hline S1- context reformation & 8 & 3 \\
\hline S5- existence of valuable historical factors & 9 & 4 \\
\hline $\begin{array}{l}\text { T3- modification of context ruined spaces to a } \\
\text { center for criminals and outlaws }\end{array}$ & 10 & 5 \\
\hline W1- low literacy of residents & 11 & 1 \\
\hline $\begin{array}{l}\text { O3- potential to set up regulations due to } \\
\text { locating in historical context area }\end{array}$ & 12 & 2 \\
\hline $\begin{array}{l}\text { O5- possibility of more economic profitability } \\
\text { and exploitation is provided }\end{array}$ & 13 & 3 \\
\hline $\begin{array}{l}\text { T2- procedure of area descending population } \\
\text { and falling value of its functions }\end{array}$ & 14 & 4 \\
\hline $\begin{array}{l}\text { O1- adoption of available potentials in area in } \\
\text { order to reformation }\end{array}$ & 15 & 5 \\
\hline $\begin{array}{l}\text { W3- insecurity due to existence of wastelands, } \\
\text { abandoned and ruined lands }\end{array}$ & 16 & 1 \\
\hline $\begin{array}{l}\text { W4- low collaboration of residents in } \\
\text { reformation of eroded context area }\end{array}$ & 17 & 2 \\
\hline $\begin{array}{l}\text { T1- modification of context to a mere } \\
\text { commercial and ignorance of other people's } \\
\text { needs }\end{array}$ & 18 & 3 \\
\hline $\begin{array}{l}\text { T4- expansion of social harms and problems in } \\
\text { eroded context area }\end{array}$ & 19 & 4 \\
\hline $\begin{array}{l}\text { T5- uncertainty of investors toward investment } \\
\text { return in area }\end{array}$ & 20 & 5 \\
\hline
\end{tabular}

Resource: author's drawing

\section{Determination of Functional Priorities of Renovation and Reformation of Shahr-E-Kord City Eroded Context}

The gained results from final evaluation of SWOT factors in AHP framework shows that in strength points, providing reformation and renovation plan of eroded context, high tendency of individuals for reformation and renovation in area, long-term residence of people in area are respectively the most important strengths, utilization of available potentials in context in order to renovation, reformation and reconstruction, enhancement of district economic grade are from the most important opportunities and limited affordability of residents in context for contribution in context reformation, uncertainty of investors to return of the fund are respectively from most threats. Existence of narrow and impermeable thoroughfares, lack of parking lots are from the most important threats in under-study area. Thus, the results from integration of SWOT and AHP factors depicts that in general, among 20 SWOT priorities, these have the most efficiency, that are the superior priorities of strengths, weaknesses, opportunities, and threats to intervene in Shahr-e-kord eroded context as follows:

Table 6: Final Intergroup Priority Matrix of SWOT Factors for Optimization of Shahr-E-Kord Eroded Context

\begin{tabular}{|l|l|l|}
\hline SWOT intergroup factors & $\begin{array}{l}\text { AHP } \\
\text { final } \\
\text { weight }\end{array}$ & $\begin{array}{l}\text { Final } \\
\text { priority }\end{array}$ \\
\hline S3- long residence of individuals in context & 0.0468 & 1 \\
\hline O2- enhancement of district economic level & 0.455 & 2 \\
\hline $\begin{array}{l}\text { T3- modification of context ruined spaces to a } \\
\text { center for criminals and outlaws }\end{array}$ & 0.455 & 3 \\
\hline $\begin{array}{l}\text { W2- disproportion of expense and income of } \\
\text { families in eroded area }\end{array}$ & 0.34 & 4 \\
\hline $\begin{array}{l}\text { W4- low collaboration of residents in } \\
\text { reformation of eroded context area }\end{array}$ & 0.34 & 5 \\
\hline S4- concentration of economic activities & 0.262 & 6 \\
\hline $\begin{array}{l}\text { O4- potential to attract private investment } \\
\text { regarding private ownership }\end{array}$ & 0.24 & 7 \\
\hline $\begin{array}{l}\text { T2- tendency of population declination in area } \\
\text { and descending value of functions }\end{array}$ & 0.24 & 8 \\
\hline W1- low literacy of residents & 0.18 & 9 \\
\hline $\begin{array}{l}\text { S2- high tendency of people in reformation of } \\
\text { context }\end{array}$ & 0.131 & 10 \\
\hline $\begin{array}{l}\text { O3- potential to set up regulations due to } \\
\text { locating in historical context area }\end{array}$ & 0.12 & 11 \\
\hline $\begin{array}{l}\text { O5- possibility for more economic profitability } \\
\text { and privilege is provided }\end{array}$ & 0.12 & 12 \\
\hline $\begin{array}{l}\text { T1- modification of context to a mere } \\
\text { commercial and ignorance of other people's } \\
\text { needs }\end{array}$ & 0.12 & 13 \\
\hline $\begin{array}{l}\text { T4- expansion of social harms and problems in } \\
\text { eroded context area }\end{array}$ & 0.12 & 14 \\
\hline $\begin{array}{l}\text { W3- insecurity due to existence of wastelands, } \\
\text { abandoned and ruined lands }\end{array}$ & 0.09 & 15 \\
\hline S1- context reformation & 0.069 & 16 \\
\hline S5- existence of valuable historical factors & 0.069 & 17 \\
\hline $\begin{array}{l}\text { O1- adoption of available potentials in area in } \\
\text { order to reformation }\end{array}$ & 0.064 & 18 \\
\hline $\begin{array}{l}\text { T5- uncertainty of investors toward return of } \\
\text { investment in area }\end{array}$ & 0.064 & 19 \\
\hline $\begin{array}{l}\text { W5- low contribution in investment by investors } \\
\text { in context reformation }\end{array}$ & 0.051 & 20 \\
\hline Resour: & & \\
\hline
\end{tabular}
Resource: writer's drawing

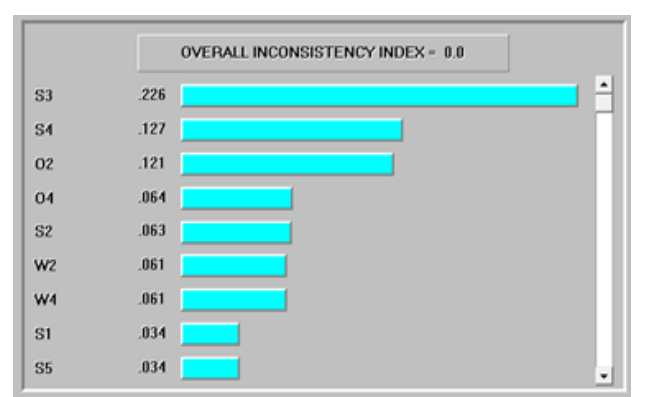

Fig. 5: Indexes final weight by EC software Writer's drawing

For this, it should be attended to a targeted and sustainable planning to inforce the strengths, proper adaptation of opportunities and facing with existing threats in line with the reformation of area.

\section{Providing Strategies and Policies of Urban Reformation and Renovation in Shahr-E-Kord Eroded Context via Integration of SWOT Strategic Analysis Model}

As it is discussed in different research stages, reformation and renovation of urban eroded fabrics has different aspects, therefore its strategies and mechanisms should be suggested in different aspects. Accordingly, through integration of SWOT analytic model results, the strategies and mechanisms of reformation and 
renovation of urban eroded fabrics in Shahr-e-kord city are divided to four aggressive, diversity, revision, and defensive strategies:

4.4. providing strategies and mechanisms for urban reformation and renovation in Shahr-e-kord eroded context through integrating SWOT strategic analytic model

\subsubsection{Aggressive/Competitive Strategies (SO)}

- Provision of scheme and arrangement of instauration and reformation plans based on residents' request and compatible to economic, social, skeletal characteristics in eroded context area in order to enhance life quality, enforcement and promotion of area identity.

- Integration of sense of belonging of Shahr-e-kord native residents toward origin of city for reformation of the city eroded context.

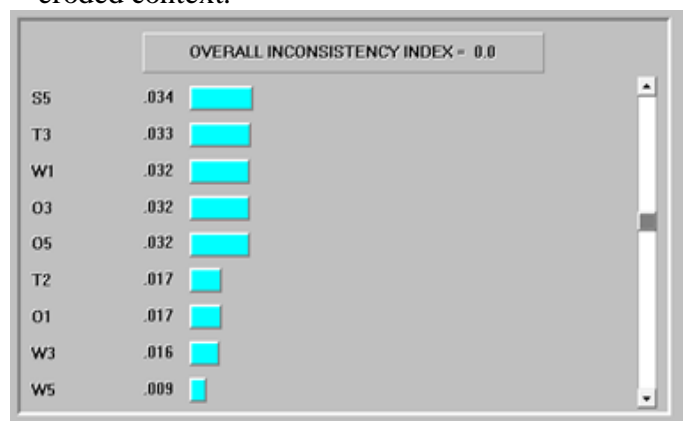

- Existence of powerful economic-social centers around the context area such as Mellat, 12 Moharram, Vali Asr, and Khajeh Nasir streets for economic flourishing of city eroded context area.

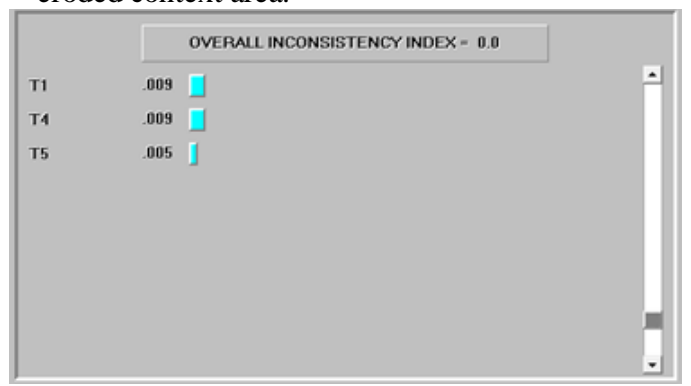

- Development of Shrine do-khatoon by construction of two new seraglios, adjunction of Hosseiniyeh and Zayersara for economic prosperity of area and the city accordingly.

- Establishment of a roofed market in a way that connects the walkway passages of Shrine courtyard to the street ... and as a factor to attract people toward the Shrine and economic flourishing of district.

- Placement of Mellat street as a commercial and social core for development and occupation of target area.

- Declination of social vulnerabilities inside Shahr-e-kord eroded context through development of cultural centers in eroded context.

\subsubsection{Diversity Strategies (ST)}

These strategies are concentrated on internal strengths and external threats and it has aimed in these strategies to provide diversity in services and amenities to attract development inspirations and preserving the current residents, thus, the following issues could be suggested for better reformation of Shahr-e-kord eroded context:

- Diversification to available amenities and services for contentment of residents and attraction of high-profiles to area as well as diminishing of others' negative attitude toward settlement in this town district.
- Allocation of taxes and complications discounts, aiming at directing people and investors of private sector to follow the rules in development of eroded context.

- Provision of different protective mechanisms and establishment of diverse investment fields to attract investors toward the context in terms of context potential to return the fund.

- Presentation and practice of locational plans in wastelands in order to enhance the social security of context.

- Improvement of life quality and environmental indexes of Shahr-e-kord eroded context.

\subsubsection{Revision Strategies (WO)}

In revision strategies further to focus on internal weaknesses, it is attempted to integrate the external opportunities in order to remove the weaknesses and obstacles in reformation of eroded context. Actually, these strategies aim at revising previous practices. As for these issues, the following options could be suggested:

- Location of eroded context in city core is one of privileges that would facilitate the reformation of urban eroded context in case of correct planning to make use of these conditions; because this opportunity could be an inspiration in diverse skeletal, economic, and social areas.

- Private investors' attraction in order to facilitate the context reformation procedure and troubleshooting of the facing problems by the context (construction of public parking).

- Integration of modern technologies, methods and equipment to prevent the inefficient and low quality development in area.

- Development of technical and practical activities, basic skills in order to provide minor and sustainable occupations to enforce the family affordability.

- Abatement policies for the proprietors in eroded context featuring restoration complications.

\subsubsection{Defensive Strategies (WT)}

These strategies focus on internal weaknesses aiming at mitigation of vulnerabilities raised by threats:

- Absence of supervision on developments aids the unofficial accommodation expansion, because in these conditions, low income people may purchase dwelling; thus, through legalization of construction and the control upon it, the expanded intrusion of immigrants to eroded context could be harnessed.

- Ignoring the housing quality in area is one of the factors that results in natives' immigration. Reformation and quality enhancement of houses and perspective and definition of open recreational spaces as greenings in core (quarter), the Shrine neighborhood of local Dokhatoon for appropriate practical use and enhancement of environmental conditions to provide more residents' social interactions.

Removing environmental problems stemming from destruction for reformation in this part of city.

- Pulling out the eroded context of Shahr-e-kord from sustainable poverty circle and providing ubiquitous opportunities for growth and prosperity of residents in this area for implementation of citizen rights.

- Reformation and widening the inner thoroughfares could have positive effect on mitigation of under-study district insecurity level. 
- To provide minimum thoroughfare network considering the license plate collection project, solving the commutation problem inside the area.

- Environmental process of project field along with localization of greening in different scales through integration of last significant visions in design of urban landscapes in the world.

- Offering long-term bank facilities to the district settlers for reformation

- Providing commercial uses like retails in locale that meets the requirements of residents.

- Enhancement of thoroughfare network quality and urban facilities through their reformation

\section{Recommendations and Practical Strategies to Gain Desirable Situation}

Establishment of public unions that their goal is not selfprofitability, but it is to provide profitability for the society against private ownership. These lots could be used for development of public spaces by allocating housing for low-income individuals.

- Engagement of settlers in this area to develop and practice the project by themselves, which may take place through development of corporations, financial aids and donating loans.

- Enforcement of rules for common contribution of banks with institutes and private enterprises for reformation and use modifications.

- The procedure of eroded context reformation should be designed in a way that leads to a context with culturalsocial identity and in compliance with technical standards. Supervision on such principles may result in optimized integration of available limited resources.

- Consensus of residents in purchasing houses, because their only asset may be the house that they reside in. Thus, the property of these types of residents should be bought for a value that they could afford a house in another quarter of the city.

- Provision of infrastructure services and installations in old context prevents the residents from neighborhood egression.

- Providing affordability for residents of eroded contexts, instauration of eroded context, generally brings about significant added value. This procedure should be designed in a way that the proprietors in eroded area also benefit from it, as otherwise, they are not able to reside in appropriate urban contexts and will relocate to other eroded fabrics. In case of failure to make the eroded context residents enough wealthy, actually a problem related to an eroded context will be transmitted to other contexts. On the other hand, due to appropriate housing supply to these groups in renovation procedure and increasing demand from the other hand, the housing cost in family expense basket will be ascended for lowincome public.

- Prevention from speculation in reformation of eroded contexts; due to the connection with inner city markets which entails intense fluctuation, it is prone to land speculation. Thus, given the vital role of these lands, as the only remained chance to solve city problems, the attitude of context reformation should be in a way to prevent from land speculation.

- Prompt and absolute instauration and reconstruction; prolongation of eroded context reconstruction leads to fading of inspiration by private sector or responsible organizations in reformation procedure. Further, because the instauration and reconstruction procedures affect people's life in area, the time of project initiation is of great importance.

- Concentration enhancement; the most common way to economize forced proprietary projects is the enhancement of density in desirable area. It is important to notice that adopting this policy alone may result in inappropriate urban skeletal space. As, over-intensification of density results in degradation of regional land value.

- Use modification; another method to economize forced proprietary projects is the shift of residential use to commercial use in eroded area. The considerable point in commercial use modification is that any context only needs a certain percentage of use modification as to its own need. Vast use modification results in declination in commercial use modification capability in peripheral areas.

- Take advantage of public subsides; in this method the government allocates subside to this interest rate because of high interest rate of bank loans.

- The most important problem in instauration of eroded contexts is ignoring the proprietors in provided added value for instauration and reconstruction of eroded context. Proprietorship of these contexts by their current little values or at least partly more, dose not enable the residents to obtain an appropriate dwelling and this, as mentioned, is not capable of solving any problem relevant to the dwellers of these contexts. On the other hand, as the investors choose the central city context to obtain the most profit, this policy will lead to marginalization and poverty or at least results in more density in adjacent eroded contexts. in case of disagreement of any proprietors in the district the execution of project would be postponed. Actually, due to the lack of engagement by proprietors in the project added value and the economic pressure raised from dislocation on a family, different groups of people resist against reconstruction that would result in delay in project implementation. The type and degree of engagement by these people should be considered in reformation and renovation projects.

- Reformation project should be wholly elaborated to residents and proprietors in neighborhood. They should be assured that there is no top secret information and no one can abuse it. In case no reformation plan is provided, a group as the proprietors and residents attend to design meetings and their intellectual engagement are adopted.

- In case of the proprietors are not solely capable for reformation and enforcement, appropriate developer and cooperator would be introduced. they will be engaged in all stages of partnership and will supervise the proprietors and residents in eroded lots.

\section{References}

[1] Asghari M, "Coincidence of pragmatism and post-modernism in Richard Rorety philosophy", Philosophy scientific-research quarterly, Vol.6, No.2, (2008).

[2] Afshani A, Spss practical learning in behavioral and social sciences. Yazd: Yazd university publications, (2008).

[3] Amakchi H, "Legal and legitimate tools effective on immigration of community and marginalization in 5-year period economic-social development program of state", Seven cities quarterly, Vol.3, (2017), pp.9-10.

[4] Bahreini H, Modernism, post-modernism and afterward in urbanism. Tehran: Tehran university publications, (1999).

[5] Bouchani M, "Renovation of Ghazvin archaic fabric a test for urban management", Municipalities management, Vol.6, No.32, (2004).

[6] Papeli Yazdi MH \& Rajabi S, City and suburb theory. Tehran: semat publications, (2003). 
[7] Tavasoli M, "Archaic context an introduction to subject, whole papers of survival seminar in archaic context of Iran cities, industry and science university", Tehran, (1993).

[8] Jahanshahi, M, Eroded context and urban development, Vol.4, No.18, (2003)

[9] Haeri, MR, "Fading of historical city in insignificancy of urban growth history", Abadi Journal, Vol. 2, No. 6, 1992.

[10] Habibi K, Pour Ahmad, A and Meshkini, A. Reformation and renovation of archaic contexts. Kordestan: Kordestan university publications, (2007)

[11] Habibi M. Historical contexts reconstruction. Tehran: Tehran University Fine Arts Faculty publications, (1996).

[12] Habibi M \& Maghsoudi M. Urban Restoration. Tehran: Tehran university publications, (2002).

[13] Hosseini J. Civic sustainable engagement in renovation and reconstruction of urban eroded contexts. Mahsad: Sokhan Gostar publications, (2008).

[14] Hekmat Nia H \& Mousavi MN. Model integration in Geography featuring urban and regional planning. Yazd: modern science publications, (2006).

[15] Hanachi P. Urban restoration in Iran's historical cities. Architecture PhD thesis, (1999).

[16] Soltan Zadeh H. Urban spaces in historical fabrics of Iran. Cultural researches office of Iran collaborating Tehran municipality. State statistical annals. (2008).

[17] Shafaghi S. Development of urban archaic and eroded contexts, paper series of urban contexts specialty congress, urbanism and housing ministry, Mashad, (1997).

[18] Shafiei Nasab SR \& Kalabi F, Eroded context and housing quality improvement policies. Abadi Journal, Vol.55, No.113, (2007).

[19] Shokouei H. Cities Social Geography and City Social Ecology. Tehran, Jahad Daneshgahi publications, (1986).

[20] Shokouei H, New ideas in Geography Philosophy. Tehran: Atlas publications, (2008).

[21] Shokouei H \& Tabrizi J. The effect of technical urban renovation on forming no-place feeling (Navab project case study). Modarres Journal, Vol. 2, (2003).

[22] Shamaei A \& Pour Ahmad, A. An analysis on policies and plans of urban renovation and reformation in state development programs. Geography quarterly, Vol.48, No.126, (2004).

[23] Shamaei A \& Pour Ahmad A. Urban renovation and reformation from the aspect of Geography. Tehran: Tehran University publications, (2005).

[24] Shamaei A \& Pour Ahmad A. Urban renovation and reformation from the aspect of Geography. Tehran: Tehran university publications, (2010).

[25] Shamaei A. Physical development effect of Yazd city on archaic fabric and reformation and instauration, (2002).

[26] Shoai F, Urbanism, Imaginations and Realities. Translated by Seyyed Mohsen Habibi, Tehran University publications, (1996).

[27] Sarafi M. Toward a theory to organize unofficial accommodation from marginalization to urbanism content. Seven cities journal, Vol. 3, No.8, (2003).

[28] Abbas Nia R, "Identification of main interior risk resources in Tehran city renovation and reformation projects", Science International Journal, Sharif Industrial University Engineering, Vol. 9, No. 8, (2008).

[29] Erfani G \& Dizani A, "Reformation from theory to practice definition of "Reformation", Term in city intervenes, Bagh Nazar quarterly, Vol.7, No.13, (2010).

[30] Azizi MM, "Evolution procedure of intervention policies in Iran's urban archaic contexts", Fine art journal of Tehran University, Vol.7, No.39, (2000).

[31] Farahani Fard S. An introduction to sustainable development in urban archaic fabrics of Iran, fine arts journal of Tehran university, Vol. 7, No. 39, (2005)

[32] Falamaki MM. A review on experiences and urban restoration from Venice to Shiraz. Ministry of roads and urban development, (1996).

[33] Falamaki MM. Instauration of monuments. Teheran: Tehran university publications, (1996).

[34] Foolad A \& Ghasemi A, "Integration of lands a method to reconstruction of eroded fabrics (Japan experience review)", Paper series of first National Congress of Reformation and Renovation of urban eroded contexts, Mashad, (2008).

[35] Gharakhloo M \& Hosseini SH, "Urban sustainable development indexes, Geography and regional development journal", Geography group of Mashad Ferdowsi Geography group, Vol. 8, No.157, (2007).
[36] Kazemi PS. Basic methods of demography. Tehran: Payam-e Noor university publications, (2008).

[37] Kalantari K \& Pour Ahmad A. Urban restoration experiences and techniques. Tehran: Jahade Daneshgahi publications, (2005).

[38] Kivister P. Fundamental Thoughts in Sociology translated by Manouchehr Sabouri. Tehran: Ney publications, (1999).

[39] Majedi H, "Development of current cities the future eroded cities", City identity journal, Vol. 4, No. 6, (2010)

[40] Ministry of state urban planning and researches. Research methods of urban development plans, study of best experiences and implementation of city development plans in Iran, Tehran: State municipalities organization publications, (1999).

[41] Ministry of state urban planning and researches. City development, architecture, and master plans' regulations, (1991).

[42] Mashadi ZDN. An analysis on urban planning in Iran. Tehran: Science and Industry University publications, (1995).

[43] Moghanlou M. The people engagement place in reformation of eroded context and effective elements on its enhancement (case study: central area of Javadieh), master degree thesis, architecture and art faculty of Islamic Azad university-central Tehran, (2010).

[44] Mehdi Zadeh J, Strategic planning of urban development (universal recent experiences and its place in Iran). Tehran: municipality and housing publications, (2006).

[45] Movahed A \& Heidarian M, "Study of the role of cultural and social factors in empowerment of urban eroded context", Paper series of national congress of urban eroded contexts, Ahvaz, (1998).

[46] Mohammadi DCM \& Zangi Abadi, A. Feasibility of Ecotourism capabilities in Chahar Mahal va Bakhtiari province through SWOT. Ecology Journal, Vol. 34, No. 47, (1998).

[47] Nikzad, A. The history of Chahar Mahal va Bakhtiari. Tehran: Giti publications, (1994).

[48] Yavar B. Engagement and place of Engagement in urban city, realities, goals, and strategies, Master degree thesis, urban developing and art faculty of Industry and Science university, Tehran, (2001).

[49] Buton B. Urban Economic, London, Macmillan. Publisher, (1985).

[50] Campell S. Readings in Planning theory, Blakwell, Oxford, (1997).

[51] Carey C. Planning for sustainable accessibility: The implementation challenge. Curtin University, (2008).

[52] Eagletion T. The Illusion and Social Theory. Blakwell, Oxford, (2008).

[53] Juliet C \& lorett A. Gentrification. Journal of regional and urban research vol. 17, (1995).

[54] Ozlem G. Urban regeneration and increased competitive power: Ankara in an era of globalization .Cities, Vol. 26, (2009).

[55] Payam N. Urban Geography. John Wiley and sons, INC. U.S.A (1975)

[56] Paul B. Urban land Economics. Machmillan, Ltd, U.K, 1988.

[57] Rosemary D. City center regeneration through residential development: Contributing to sustainability. Urban Studies, Vol.42, No.13, (2005)

[58] Releigh B. Land Resource Economics. Prentic- Hall U.S.A, (1985).

[59] Robert H. Inner City Regeneration. Spon, Ltd, U.K, (1982).

[60] Roberts P. The evolution, definition and purpose of urban regeneration, in $P$. Roberts and $H$. Syke(eds). Urban Regeneration, A Handbook. British Urban 'Regeneration Association, SAGE Publications ،London, (2000).

[61] Development planning unit, university college London.

[62] Wilson J. Urban renewed. The record and the controversy, the M.I. Press, (1973).

[63] www.unisdr.org 